\title{
Grafizacja w prasie, czyli o kilku przykładach organizacji przestrzennej tekstów prasowych
}

Tekst w mediach jest działaniem interakcyjnym, tworzonym ze względu na wzajemne oddziaływanie jego nadawcy oraz odbiorcy. Tekst prasowy jest pewnego rodzaju dialogiem między dziennikarzem a czytelnikiem. Ten dialog pojawia się na wielu poziomach tekstu, również w prezentacji jego szaty graficznej.

Maryla Hopfinger stwierdza, że „słowo pisane dzisiaj szuka swojej tożsamości, różnej od mowy i jej naśladowania, zabiega o uzyskanie odrębności w stosunku do języka mówionego. Przywiązuje dużą wagę do swego zapisu, do strony wizualnej przekazu, wizualizuje się"'. Współczesna prasa zmienia swoje tradycyjne oblicze właśnie ze względu na zmiany społeczno-kulturowe. Sam zapis tekstu w prasie ulega przeobrażeniom. Tim Harrower w Podręczniku projektanta gazet pisze: „wyobraźcie sobie, że dawno temu ludzie naprawdę lubili czytać gazety. Rzucali gazeciarzowi monetę, chwytali ulubione pismo i wpatrywali się w krzyczące tytuły, [...] w długie szare szpalty druku [...] i wołali: «Do licha! Ileż tu informacji!». Dziś jesteśmy inni. Mamy kolorową telewizję, osobiste komputery [...], jaskrawe czasopisma. [...] Czytanie wielkich połaci zadrukowanego papieru uważamy za stratę czasu" ". Tym samym zmienia się odbiór tekstów prasowych, możemy dziś bowiem mówić o „dziennikarstwie wizualnym”. Renata Gluza stwierdza, że czytelnicy są wychowani na obrazach i tego samego oczekują od prasy. Autorka swoją tezę opiera na amerykańskich badaniach, w których eksperymentowi poddano dziewięćdziesięciu czytelników gazet codziennych (były to osoby w wieku od 25 do 43 lat, które co najmniej cztery razy w tygodniu czytały gazetę codzienną). Dzięki kamerom zamocowanym na głowach badanych można było śledzić ruchy ich oczu. Wyniki pokazały, że 75 procent badanych oglądało zdjęcia ( 80 procent badanych czytało

\footnotetext{
* Dr, e-mail: magdalena.slawska@us.edu.pl; Uniwersytet Śląski, Wydział Nauk Społecznych, Instytut Nauk Politycznych i Dziennikarstwa; ul. Bankowa 11, 40-007 Katowice.

${ }^{1}$ M. Hopfinger, Doświadczenia audiowizualne. O mediach w kulturze wspótczesnej, Sic!, Warszawa 2003, s. 134.

${ }^{2}$ T. Harrower, Podręcznik projektanta gazet, tłum. W. Horabik, Z. Domaniewska, exPress, Warszawa 2006, s. 2.

${ }^{3}$ Por. R. Gluza, Dziennikarstwo wizualne, „Press” 2002, nr 3, s. 44.
} 
infografiki i oglądało rysunki). Tylko 25 procent badanych czytało teksty (choć ponad połowa czytała wszystkie tytuły). Eksperyment pokazał, że za miejsca istotne w tekście prasowym uznajemy przede wszystkim fotografie i infografiki (ale także tytuły) - to one zachęcają nas do lektury tekstów ${ }^{4}$. Warto w tym miejscu podkreślić, że prasa jest medium wizualnym ${ }^{5}$, które oddziałuje na czytelnika poprzez swoją szatę graficzną. W artykule zaprezentuję przykłady grafizacji tekstów prasowych w organizacji przestrzennej strony oraz w strukturze tekstów prasowych.

\section{Tekst prasowy jako makrostruktura}

Kazimierz Michalewski wskazuje, że „na układ gazety składa się jej graficzna makrokompozycja - całościowy graficzny wzór strony (głównie tytułowej) i gazety jako całości, a także mikrokompozycja - graficzne rozmieszczenie składników artykułu, nagłówka, zastosowanie fotografii, ilustracji, map, tabelek, diagramów itp.”. Na całościowy kształt strony w gazecie ma wpływ układ przestrzenny tekstu, czyli szerokość szpalt, proporcje światła (przestrzeń niezadrukowana), stosowanie elementów graficznych, zróżnicowany wygląd tytułów i lidów, wreszcie rozmieszczenie fotografii i infografik. Te wszystkie elementy tworzą layout gazety?

Kiedy analizuje się teksty prasowe z punktu widzenia ich struktury, organizacji przestrzennej, strony graficznej, przydatne okazują się pojęcia lingwistyki tekstu czy analizy dyskursu. Bo nawet jeśli nazwiemy pojedynczy tekst prasowy za autorem monografii Komunikaty mieszane „mikrokompozycją” (a nie jak w lingwistycznej analizie tekstu „makrostrukturą"), to jest to pewnego rodzaju zorganizowana przestrzeń tekstowa i bez problemu odszukamy w niej miejsca strategiczne. Urszula Żydek-Bednarczuk wskazuje, że „każdy tekst ma swoje pozycje strategiczne, to znaczy takie, na których zwiększa się uwaga odbiorcy, jednocześnie pozycje te są celowo konstruowane przez nadawców. [...] Pozycje te przyciągają uwagę odbiorcy i pozwalają lepiej przygotować i przetwarzać informacje"». Anna Duszak także identyfikuje miejsca kluczowe dla tekstu:

\footnotetext{
${ }^{4}$ Por. tamże, s. 44.

${ }^{5}$ Por. W. Furman, Gatunki dziennikarskie w praktyce redakcyjnej, [w:] K. Wolny-Zmorzyński, A. Kaliszewski, W. Furman, Gatunki dziennikarskie. Teoria, praktyka, język, Wydawnictwa Akademickie i Profesjonalne, Warszawa 2006, s. 158.

${ }^{6}$ K. Michalewski, Komunikaty mieszane, Wydawnictwo UŁ, Łódź 2009, s. 115-116.

${ }^{7}$ Por. G. Ambrose, P. Harris, Layout. Zasady, kompozycja, zastosowanie, Wydawnictwo Naukowe PWN, Warszawa 2008. Por. M. Worsowicz, Edytorstwo prasowe - zagadnienia ogólne, [w:] O mediach i komunikacji. Skrypt dla studentów dziennikarstwa i komunikacji społecznej, red. E. Pleszkun-Olejniczakowa, J. Bachura, M. Worsowicz, Wydawnictwo UŁ, Łódź 2010, s. 129-140.

${ }^{8}$ U. Żydek-Bednarczuk, Wprowadzenie do lingwistycznej analizy tekstu, Universitas, Kraków 2005, s. 171.
} 
tego rodzaju zjawiska tekstowe analizuję pod hasłem orientacja $w$ dyskursie, jako że ułatwiają one ludziom orientowanie się w świecie tekstu. Chodzi tu o sygnały, które jakby organizują przestrzeń tekstową, wytyczają jej punkty strategiczne, a tym samym pomagają odbiorcy ustalać, w jakim miejscu się znajduje i w jaką stronę powinien zmierzać, dążąc do całościowej interpretacji danego zdarzenia tekstowego?

Obie te autorskie wypowiedzi przypominają dialogowy charakter tekstu, w którym nadawca prowadzi swojego czytelnika przez kolejne partie tekstu. Jednocześnie idealnie obrazują topografię gazety. Miejsca strategiczne tekstu wiążą się wyraźnie z miejscami ważnym od strony edytorskiej, projektowej gazety.

Do pozycji strategicznych i jednocześnie zaprojektowanych graficznie w makrokompozycji strony w gazecie zaliczam:

- tytuły i lidy;

- fragmenty inicjalne i finalne wypowiedzi, funkcjonujące jako rama delimitacyjna tekstu ${ }^{10}$ (fragmenty inicjalne często będą graficznie zaznaczone jako miejsca wejścia w tekst, elementem finalnym przykładowo będzie podpis autora tekstu);

- wyraźnie zaznaczone graficznie elementy segmentacji tekstu (śródtytuły);

- wyimki tekstowe (wyeksponowany graficznie fragment tekstu) ${ }^{11}$;

- elementy stowarzyszone z tekstem: grafiki, infografiki, fotografie, podpis pod fotografiami, dodatkowe teksty stowarzyszone, takie jak sylwetka.

Wymienione przeze mnie miejsca orientacji w tekście ${ }^{12}$ to jednocześnie elementy widoczne graficznie w strukturze tekstu. To one ułatwiają poruszanie się po tekście prasowym, nawigują i przede wszystkim zachęcają czytelnika do zapoznania się z tekstem głównym, czyli korpusem tekstu prasowego, zatem ułatwiają jego odbiór. Monika Worsowicz pisze o tym, że ,sposób odbioru dziennika ewoluował od lektury - typowej dla czytelnika samodzielnie wędrującego wzrokiem po kolumnie, przez pilotaż polegający na sugerowaniu, z czym warto się zapoznać, do nawigowania, podczas którego wzrok wędruje po precyzyjnie zaprojektowanych elementach strony"13. Badacze wskazują także, że czytanie gazet

${ }^{9}$ A. Duszak, Tekst, dyskurs, komunikacja międzykulturowa, Wydawnictwo Naukowe PWN, Warszawa 1998, s. 127.

${ }^{10}$ Por. T. Dobrzyńska, Delimitacja tekstu literackiego, Zakład Narodowy im. Ossolińskich, Wrocław 1974, s. 5-7.

${ }^{11}$ Por. M. Wojtak, Analiza gatunków prasowych. Podręcznik dla studentów dziennikarstwa i kierunków pokrewnych, Wydawnictwo UMCS, Lublin 2008, s. 18, 31-38.

12 Badacze do przytoczonych przeze mnie pozycji strategicznych dodają także strategie nadawczo-odbiorcze, elementy retoryczne i metatekstowe. Por. U. Żydek-Bednarczuk, dz. cyt., s. 180-186. Por. A. Duszak, dz. cyt., s. 149-160.

${ }^{13}$ M. Worsowicz, Lektura, pilotaż, nawigowanie - o grafizacji materiałów dziennikarskich na przykładzie jedynek „Dziennika Łódzkiego”, [w:] Komunikacja wizualna w przestrzeni społecznej, red. A. Obrębska, Wydawnictwo Primum Verbum, Łódź 2009, s. 102. 
poprzedzone jest ich wstępnym „skanowaniem”"14, czyli zindywidualizowanym typem odbioru, w czasie którego czytelnik szuka najpierw miejsc najbardziej atrakcyjnych i przyciągających uwagę.

\section{Tekst prasowy - gatunek - struktura}

Próbując opisać grafizację tekstów prasowych, przywołam pojęcie gatunku, który jest swoistą formą, wzorcem tekstu. Jednym z aspektów gatunkowych jest aspekt strukturalny (model kompozycyjny tekstu) ${ }^{15}$. W obrębie gatunków prasowych odnajdziemy takie, które rozpoznamy tylko i wyłącznie po strukturze tekstu (nie czytając ich, a jedynie wstępnie „skanując”). Przywołam je ze względu na widoczną strukturę, ale chcę podkreślić, że to właśnie ona wpływa przecież na odbiór tekstu, zatem przy analizie gatunków nie sposób pomijać chociażby aspektu pragmatycznego (należy je analizować całościowo). Jednak dla podkreślenia istoty strony graficznej tekstów prasowych wymienię te gatunki, których organizacja przestrzenna pozwala je bez trudu identyfikować.

Do takich gatunków z pewnością zaliczymy wywiad prasowy, ponieważ dialogowy charakter tekstu jest widoczny w jego strukturze. Forma dialogu w prasie jest graficznie sygnalizowana przez: zastosowanie myślników, wcięć akapitowych, obrazujących poszczególne głosy w dialogu, oraz zdecydowanie większą operację światłem (czyli przestrzenią niezadrukowaną) w tekście.

Kolejnym gatunkiem wyraźnie graficznym będzie felieton, który jako jeden z niewielu ma swoje wyznaczniki zewnętrzne, czyli wyraźnie strukturalne: felieton to niewielki tekst opatrzony zdjęciem autora, jego podpisem, często wyróżniony graficznie, który cyklicznie pojawia się w tym samym miejscu w prasie ${ }^{16}$ (tu należy dodać, że podobnie strukturalnie wygląda komentarz autonomiczny). Marek Meissner stwierdził nawet, ,że felietonem jest każdy tekst, który wydrukowano kursywą"'17, co oznacza, że felieton jest na tyle gatunkiem otwartym, pojemnym, trudnym do uchwycenia w wyznacznikach wewnątrzgatunkowych, a one jednocześnie są zbyt szerokie, że najłatwiej rozpoznać go właśnie po układzie przestrzennym, po grafii.

Gatunkiem, który ma wyraźny sygnał graficzny, jest także zapowiedź prasowa. Graficzny element to formuła odsyłająca (odsyłacz) do tekstów wewnątrz

${ }^{14}$ G. Kress, T. van Leeuwen, Front Pages: (The Critical) Analysis of Newspaper Layout, [w:] The Discourse Structure of the News Stories, ed. A. Bell, P. Garett., Oxford 1998, pp. 187-188, za: T. Piekot, Dyskurs polskich wiadomości prasowych, Universitas, Kraków 2006.

${ }^{15}$ M. Wojtak, Gatunki prasowe, Wydawnictwo UMCS, Lublin 2004, s. 16.

${ }^{16}$ Por. tamże, s. 204.

${ }^{17}$ A. Niczyperowicz, Felieton-piękny pasożyt, [w:] Dziennikarstwo od kuchni, red. A. Niczyperowicz, TS Wydawnictwo, Poznań 2001, s. 86. 
numeru typu: „,zytaj s. X”, „,szczegóły s. X”, „,szerzej na s. X”, „więcej s. X”. Zapowiedź bowiem to gatunek informacyjny pełniący funkcję wstępnego powiadamiania o określonym fakcie, o problemie czy opinii i zarazem o tekście drukowanym wewnątrz gazety ${ }^{18}$.

Myślę, że poprzez strukturę można także rozpoznać seryjne wzmianki, seryjne recenzje (zwłaszcza dzięki dołączonym ocenom typu „gwiazdki”) czy listy do redakcji ${ }^{19}$, ponieważ ich struktura oraz towarzyszące im znaki graficzne będą widoczne na pierwszy rzut oka.

Gatunek, który jest najlepszym przykładem wizualizacji tekstu, to infografika, czyli zgrafizowana informacja. Została ona uznana przez badaczy za gatunek samodzielny ${ }^{20}$, jest

gatunkiem czystym: nie grafiką, nie ilustracją - ale informacją. Tyle że obrazową. Może to być rysunek, schemat, tabela, wykres, obraz złożony z różnych elementów... Każda informacja wizualna może być infografiką. [...] Dwa ustawione obok siebie zdjęcia robione z tej samej odległości i perspektywy, na których widać stosunek wielkości jednego obiektu do drugiego - to też już infografika ${ }^{21}$.

Michael Robinson (mistrz infografiki prasowej, dyrektor artystyczny „The Guardian” i „The Observer”) podkreśla, że „grafika musi być tak prosta i tak naturalna, by czytelnicy mieli wrażenie, że danego tematu po prostu nie da się pokazać w inny sposób" ${ }^{22}$. Infografika powinna być przejrzysta, aby czytelnik bez trudu ją odczytał.

Oprócz infografiki warto przywołać także fotografię, bo to ona „zrewolucjonizowała prasę i zmobilizowała dziennikarzy do większej precyzji w ukazywaniu faktów i opisywaniu otaczającej rzeczywistości”23, jak podkreśla autor monografii o gatunkach fotograficznych. W komunikacie prasowym odnajdziemy przeróżne realizacje relacji słowa i obrazu ${ }^{24}$, zatem tekst w prasie należy analizować całościowo jako komunikat językowo-wizualny.

\footnotetext{
${ }^{18}$ M. Wojtak, Gatunki, dz. cyt., s. 101-103.

${ }^{19}$ Często graficznie listowi do redakcji towarzyszy niewielkie zdjęcie tekstu, do którego czytelnik nawiązuje czy z którym polemizuje.

${ }^{20}$ Por. K. Wolny-Zmorzyński, A. Kaliszewski, W. Furman, dz. cyt., s. 40.

${ }^{21}$ L. Mazurczyk, Zrozumieć infografikę, [w:] Biblia dziennikarstwa, red. A. Skworz, A. Niziołek, Wydawnictwo Znak, Kraków 2010, s. 365.

${ }^{22}$ K. Kopacz, Rzemiosto i sztuka, „Press” 2010, nr 10, s. 50.

${ }^{23} \mathrm{~K}$. Wolny-Zmorzyński, Fotograficzne gatunki dziennikarskie, Wydawnictwa Akademickie i Profesjonalne, Warszawa 2007, s. 27.

${ }^{24}$ Por. T. Piekot, Werbalizacja i wizualizacja w dyskursie wiadomości prasowych, [w:] Ikoniczność znaku. Słowo - przedmiot - obraz - gest, red. E. Tabakowska, Universitas, Kraków 2006, s. 99-116; J. Pacuła, Grafizacja i wizualizacja słowa w zapowiedziach medialnych, „Media i Społeczeństwo" 2012, nr 2, s. 74-93.
} 


\section{Grafizacja $^{25}$ w strukturze tekstu / wizualizacja tekstu}

Kazimierz Michalewski wymienia składniki wizualne komunikatów pisanych $^{26}$. Są to: grafia (wielkość oraz krój czcionki), rozmieszczenie tekstu (organizacja przestrzenna tekstu), elementy ikoniczne (ilustracje, tabele, wykresy, rysunki, fotografie), kolor, ozdobne elementy graficzne (punktory), znaki interpunkcyjne ${ }^{27}$. Wszystkie elementy zwizualizowania prasy muszą łączyć w sobie podstawowe funkcje gatunków dziennikarskich, a więc komunikatywność i funkcjonalność, a jednocześnie podkreślają atrakcyjność przekazu. Ukształtowanie szaty graficznej tekstu prasowego ma bowiem zachęcić czytelnika do jego lektury.

Grafizacji struktury tekstowej poszukiwałam w wydaniach „Dużego Formatu” (dalej też „DF”), dodatku do „Gazety Wyborczej”. Zaprezentuję takie teksty, w których grafizacja pojawi się w strukturze przestrzennej tekstów. Przydatne do analizy może okazać się samo pojęcie formy. Uznaję bowiem kształt graficzny tekstu za pewną formę tekstu, za przelanie tekstu - werbalizacji w pewną formę - wizualizacji.

Barbara Kudra zauważa, że „pod wpływem pisma zmienia się sposób organizacji tekstu, sposób myślenia oraz odbiór tekstu. Szata graficzna jest integralnym składnikiem każdego tekstu pisanego. [...] Różne zabiegi graficzne są składnikami wizualizacyjnymi tekstu. Wyróżniają one w tekście oraz wyodrębniają z płaszczyzny tekstu elementy istotne treściowo" ${ }^{28}$. Jan Grzenia podkreśla natomiast, że przyczyną grafizacji nie jest tylko upowszechnienie narzędzi umożliwiających graficzne opracowanie tekstu, ale ,jest ona naturalną konsekwencją

25 „Ważną cechą komunikacji pisanej są ścisłe - mimo różnic - związki mowy, pisma i obrazu. [...] Wśród interesujących aspektów tych zależności należy wymienić grafizację pisma, której rezultatem jest wzrost roli składnika graficznego w komunikacji pisanej. Oznacza to, iż tworzenie tekstu pisanego nie ogranicza się do nadania komunikatu, towarzyszy mu także troska autora o odpowiedni kształt wizualny tekstu" (J. Grzenia, O grafizacji pisma, [w:] Spotkanie. Ksiega jubileuszowa dla Profesora Aleksandra Wilkonia, red. M. Kita, B. Witosz, Wydawnictwo UŚ, Katowice 2005, s. 144).

${ }^{26}$ Przybliżając pojęcie komunikatów mieszanych, warto przywołać propozycję podziału gatunków przedstawioną przez Jacka Maziarskiego w 1976 r., która prezentowała podział gatunków ze względu na „tworzywo”, wymieniając podstawowe grupy: gatunki językowe, gatunki obrazowe i gatunki językowo-obrazowe. Gatunki językowe oparte są na kodzie słownym, obrazowe na kodzie wizualnym, a mieszane to językowo-obrazowe. Por. J. Maziarski, Gatunki dziennikarskie, [w:] Encyklopedia wiedzy o prasie, red. J. Maślanka, Zakład Narodowy im. Ossolińskich, Wrocław 1976, s. 90-91.

${ }^{27}$ Por. K. Michalewski, dz. cyt., s. 15-29.

${ }^{28}$ B. Kudra, Grafizacja w nagłówkach prasowych, [w:] Na językoznawczych ścieżkach. Prace ofiarowane Profesorowi Jerzemu Podrackiemu, red. A. Mikołajczuk, R. Pawelec, Wydawnictwo Naukowe Semper, Warszawa 2007, s. 155. 
potrzeby większego panowania nad wizualnym kształtem wypowiedzi pisanej"29. Wizualizacja tekstu prasowego będzie więc próbą autorskiego i redakcyjnego panowania nad kształtem tekstu.

\section{Wieloglosy - wizualizacja struktury}

Pierwszą grupą tekstów będą artykuły w formułach wielogłosowych ${ }^{30}$. Struktura tych tekstów jest podporządkowana współistnieniu kilku głosów prezentowanych jednocześnie. Owa jednoczesność podkreślona jest właśnie przez formę tekstu. Pierwszy tekst to Dzień dziecka z wrzodami żoładka („DF”, 3 lipca 2006). Wizualnie tekst składa się z pięciu wypowiedzi umieszczonych w dymkach.

Rozmieszczenie poszczególnych głosów oraz towarzyszące im rysunki przywołują komiks ${ }^{31}$. Wypowiedzi młodzieży idealnie oddaje wizualizacja tego tekstu. Oto fragment jednej z wypowiedzi:

To „wyciąganie” stopni może człowieka wykończyć. W domu cisną, że średnia za niska, w szkole grożą sprawdzianami (niektórzy to już na wrzesień zaklepują terminy). Nauczyciele podenerwowani, uczniowie zestresowani - jak tu normalnie funkcjonować? Już sama nie wiem, kto przed końcem roku ma gorsze schizy („DF”, 3 lipca 2006).

Autentyzm młodzieżowego slangu jest tu wyraźnie podkreślony ciekawą formą tekstu, ponieważ komiks, mimo swej ewolucji, ma stereotyp gatunku kojarzącego się z młodym odbiorcą.

\footnotetext{
${ }^{29}$ J. Grzenia, dz. cyt., s. 142.

${ }^{30}$ Szerzej o wielogłosach pisałam w rozdziale: $O$ wielogłosach - między głosowościa a wizualnościa tekstu, por. M. Ślawska, Formy dialogu w gatunkach prasowych, Wydawnictwo UŚ, Katowice 2014, s. 211-247.

${ }^{31}$ Więcej na temat komiksów w gatunkach pisałam w artykule: M. Ślawska, Wywiady w formie komiksu, czyli o modyfikacjach gatunkowych na tle procesów konwergencji, [w:] Konwergencja mediów i jej skutki dla współczesnego dziennikarstwa, t. 1, red. M. Wielopolska-Szymura, Z. Oniszczuk, Wydawnictwo UŚ, Katowice 2012, s. 399-408.
} 


\section{Dzień dziecka z wrzodami żotądka}

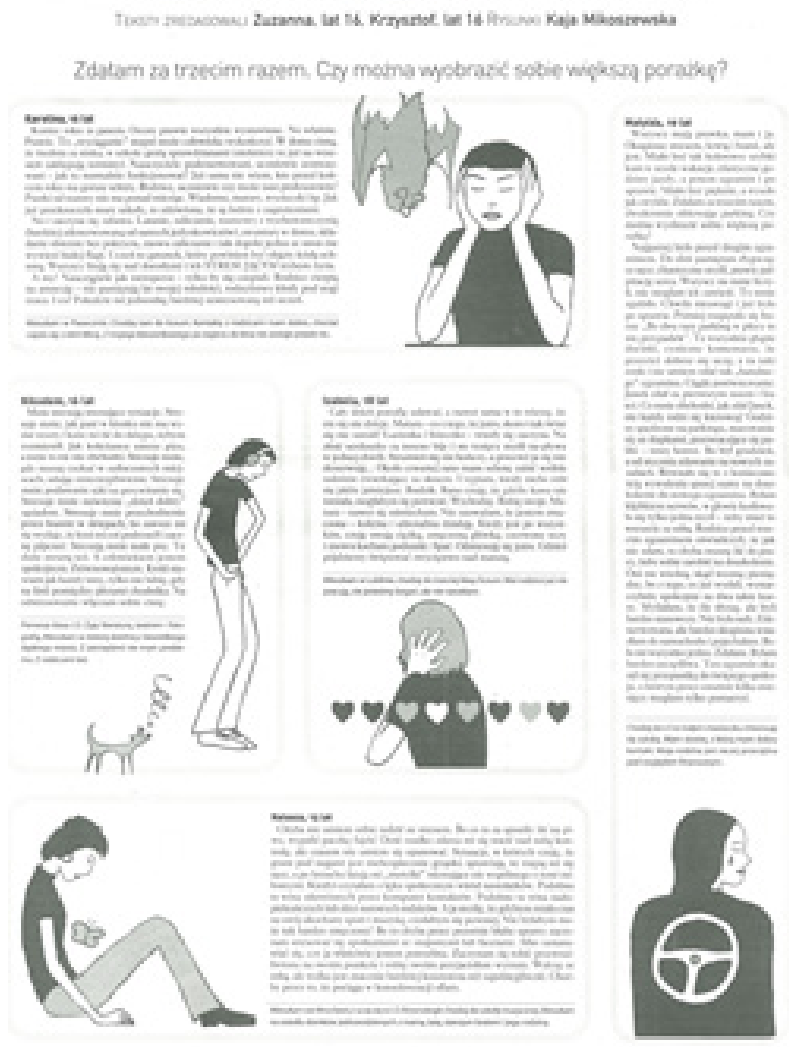

Fot. 1

Źródto: „DF”, 3 lipca 2006.

Dwa kolejne przykłady to teksty: Po co rzeź („DF”, 20 czerwca 2013) oraz Co wywiezie eurokibic („DF”, 28 czerwca 2012). Oba zbudowane są bardzo podobnie. To forma równorzędnych głosów zestawionych obok siebie. Pierwszy tekst jest zbudowany z odpowiedzi na pytanie dotyczące sensu odtwarzania rekonstrukcji historycznych, w tym przypadku rzezi wołyńskiej. Drugi przykład to wypowiedzi osób różnych narodowości, które odwiedziły Polskę w związku z Mistrzostwami Europy w Piłce Nożnej Euro 2012. Wszystkim wypowiedziom towarzyszą zdjęcia ich autorów. W przypadku komentarza są to jedynie portrety, w drugim przykładzie są to sylwetki osób ubranych w swoje barwy narodowe. Wizualnie te teksty prezentują się następująco: 


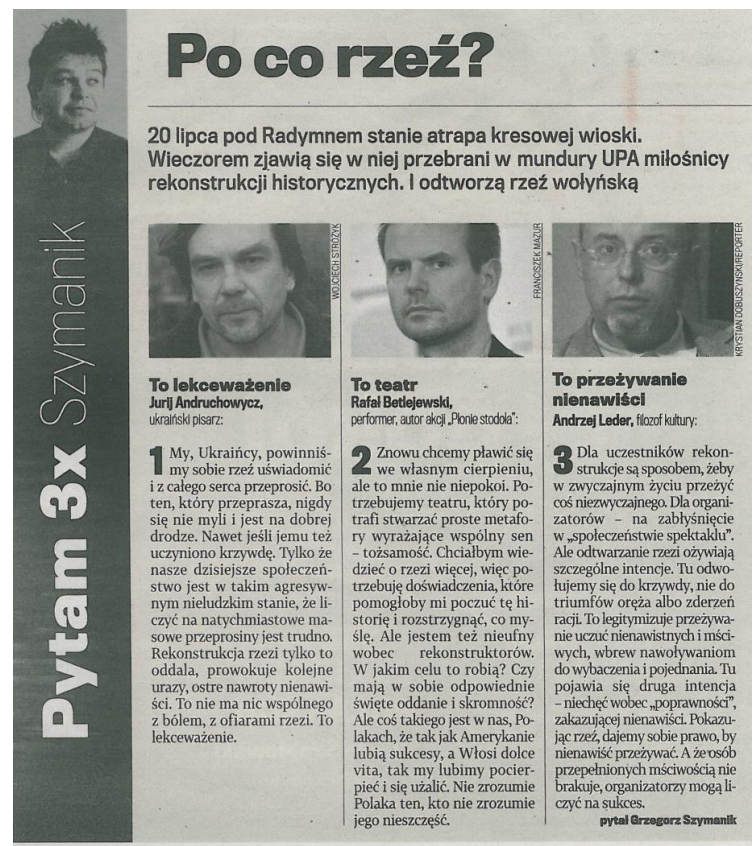

Fot. 2

Źródto: „DF”, 20 czerwca 2013.

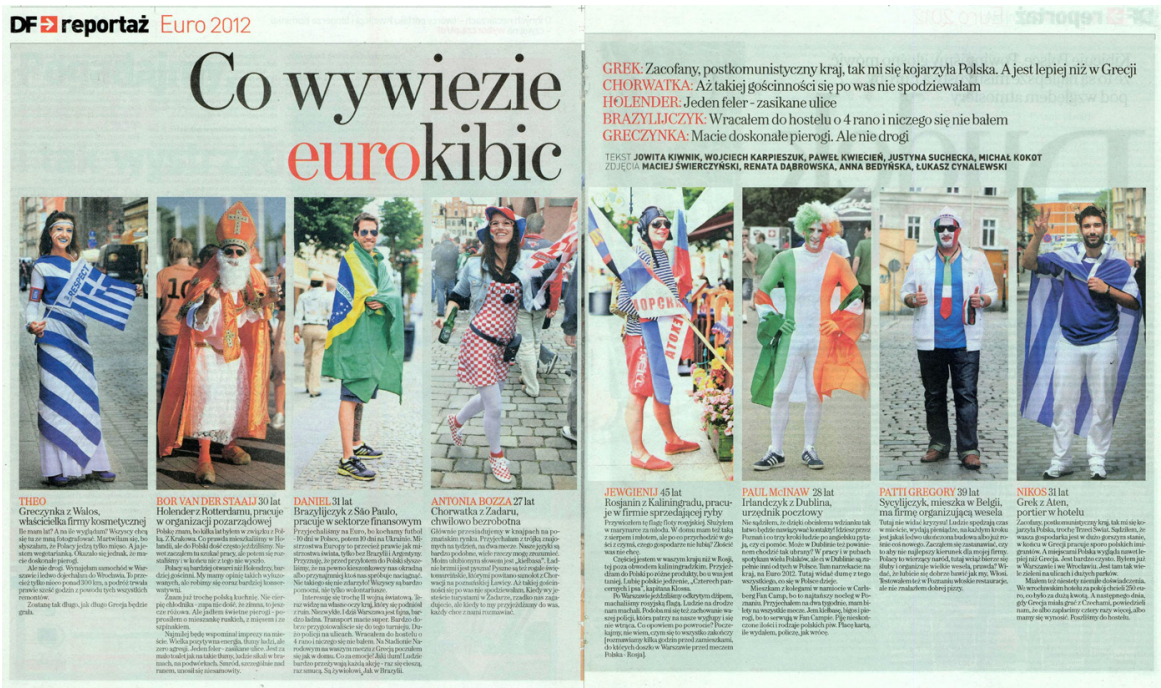

Fot. 3

Źródło: „DF”, 28 czerwca 2012. 
Przedstawione wielogłosy ilustrują sytuację, w której dynamika łamów współgra z tematyką i sposobem prezentowania rzeczywistości. Rzeczywistości, która jest wielokształtna i różnorodna ze względu na prezentację opinii przez wiele osób. Taka struktura pozwala także czytelnikowi na zupełną dowolność, jeżeli chodzi o kolejność zapoznawania się z poszczególnymi opiniami.

\section{Łamy prasowe - wizualizacja fotografii}

Kolejny przykład to tekst Karoliny Domagalskiej Urodzę za 12 tysięcy dolarów („DF”, 14 maja 2009). Jest to reportaż o macierzyństwie zastępczym przedstawiony w nietypowym układzie graficznym ze względu na szpalty ułożone w postaci ciążowego brzucha:
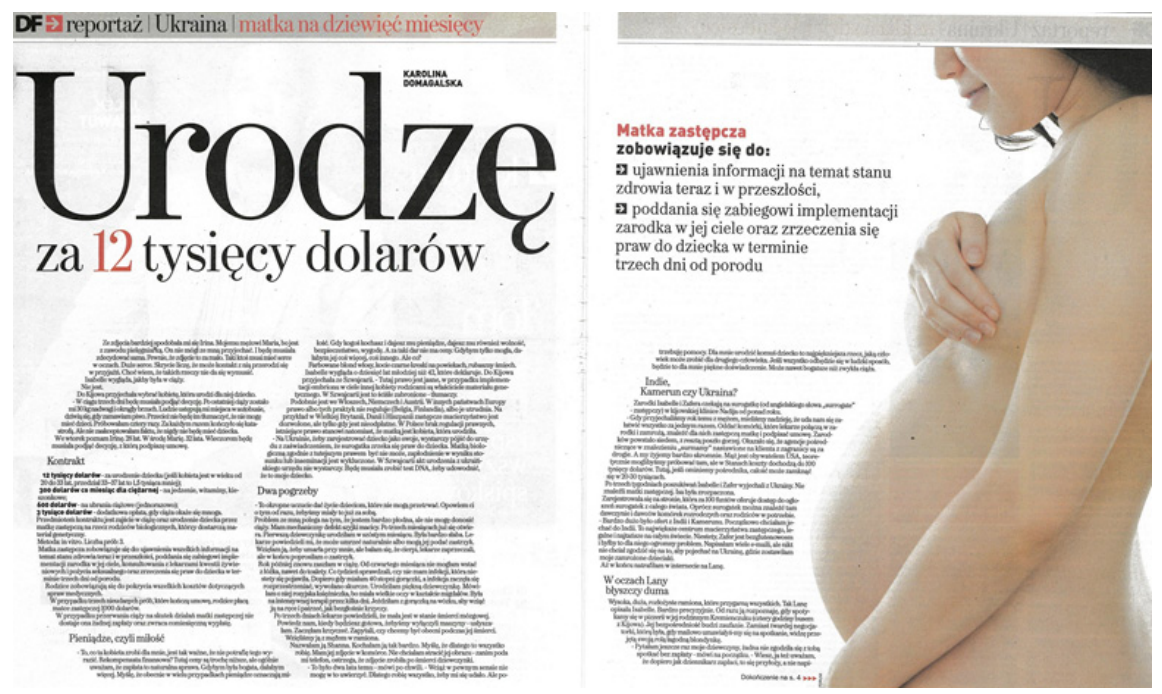

Fot. 4

Źródto: „DF”, 14 maja 2009.

Rysunek łamów prasowych to niejako wizualne odbicie fotografii kobiety w ciąży, które jest elementem stowarzyszonym z tekstem. Grafika doskonale podkreśla obrazowość tego tekstu. Dla porównania przytoczę tylko dwa fragmenty reportażu:

Wieczorem zadzwoniła Olga i powiedziała, jak minął dzień. Ile mały spał, co jadł i ile, jak go kąpali, jak smarowali oliwką, ile pampersów wymienili. I nagle zrozumiałam, skąd wzięła się moja histeria. [...] I w głowie mi zostało, że ona nie będzie 
potrafiła się tym dzieckiem zająć. Więc jak usłyszałam, że dziecko je, śpi i jest bezpieczne, natychmiast się uspokoiłam.

Gdy za drugim razem dowiedziałam się, że jestem w ciąży, zadzwoniłam do polskiej mamy i 40 minut płakałyśmy do słuchawki. Wspaniała chwila („DF” 14 maja 2009).

Rysunek łamów podkreśla wagę oraz tematykę poruszanej kwestii, ale też przenosi niejako na siebie językową, stylistyczną wrażliwość tekstu. Jest jego wizualizacją.

\section{Infografika - prowadzenie po tekście}

Kolejny tekst to reportaż Roman Kluska. Legenda o dobrym pasterzu Michała Matysa („DF”, 20 czerwca 2013), który jest ciekawie zwizualizowany dzięki dołączonej do tekstu infografice ${ }^{32}$ :

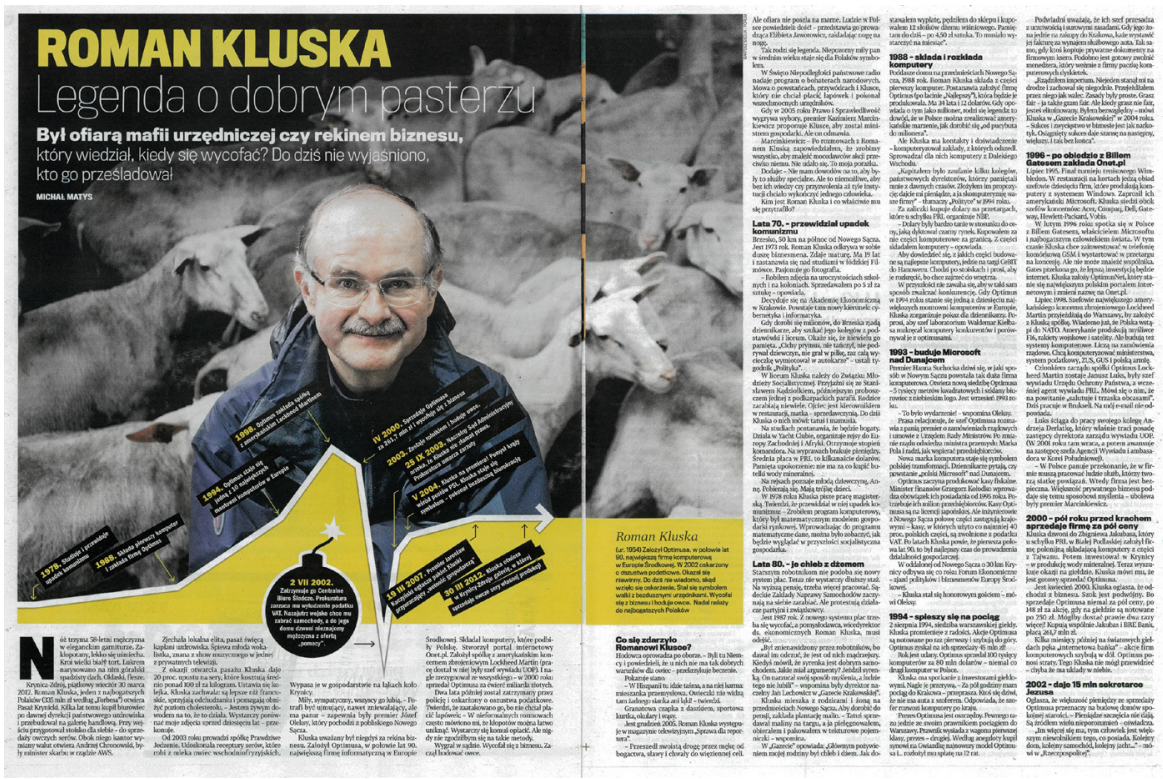

Fot. 5

Źródło: „DF”, 20 czerwca 2013.

${ }^{32}$ Por. A. Starzec, Rola infografów w tekstach prasowych o tematyce naukowej, [w:] Oblicza komunikacji 1. Perspektywy badań nad tekstem, dyskursem i komunikacja, red. I. Kamińska-Szmaj, T. Piekot, M. Zaśko-Zielińska, Krakowskie Towarzystwo Popularyzowania Wiedzy o Komunikacji Językowej „Tertium”, Kraków 2006, s. 245-257. 
Na dołączonym zdjęciu bohatera reportażu widoczny jest żółty wykres, który obrazuje jego losy. Dzięki infograficznej wizualizacji wyraźnie zaznaczony jest punkt graniczny - wówczas wykres idzie w dół i obok jest narysowana odpalona bomba z następującym tekstem:

2 VII 2002. Zatrzymuje go Centralne Biuro Śledcze. Prokuratura zarzuca mu wyłudzenie podatku VAT. Nazajutrz wojsko chce mu zabrać samochody, a do jego domu dzwoni nieznajomy mężczyzna z ofertą „pomocy” („DF”, 20 czerwca 2013).

Ta infografika jest niejako graficznym skrótem tekstu. Ale jednocześnie pełni funkcję podobną do spisu treści, ponieważ daty i krótkie opisy prowadzą nas przez cały reportaż w postaci niemal identycznych śródtytułów (tu pojawiają się te same daty, które są zaznaczone na wykresie). Infografika jest zintegrowana z tekstem prasowym, pozwala czytelnikowi szybko objąć tematykę tekstu i równocześnie przez ten tekst prowadzi, ale też idealnie go obrazuje.

\section{Tekst wpisany w grafikę}

Przykład wpisania całego tekstu w grafikę ${ }^{33}$, czyli w rysunek wyrwanej z zeszytu strony, to artykuł Krwawię („DF”, 17 maja 2012). Artykuł zajmuje cała stronę gazety i graficznie prezentuje się w taki sposób:

\footnotetext{
${ }^{33} \mathrm{Na}$ temat wpisywania tytułów w grafikę lub odwrotnie pisał Jarosław Pacuła, por. J. Pacuła,
} dz. cyt., s. 74-93. 


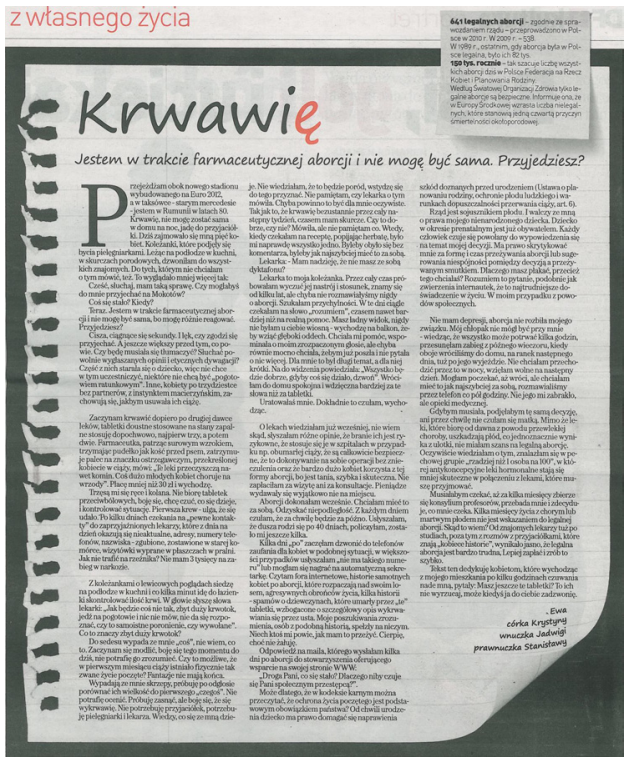

Fot. 6

Źródło: „DF”, 17 maja 2012.

Problematyka tekstu, czyli farmaceutycznej aborcji, jest podkreślona poprzez wizualizację tego tekstu, który jest prywatną, wręcz intymną relacją. Podkreśla to także podpis pod artykułem:

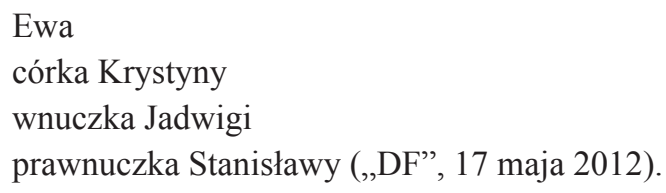

Ewa

córka Krystyny

wnuczka Jadwigi

prawnuczka Stanisławy („DF”, 17 maja 2012).

Brak nazwiska podkreśla wymowę tekstu, a wyrwana i zagięta kartka papieru obrazuje wyjątkowo osobistą treść.

\section{Gra światłem - wizualizacja przestrzeni w tekście}

Ostatni przykład, czyli wywiad Katarzyny Lubinieckiej z Iwoną K. pt. Gdyby nie umart, toby za mną tęsknił („DF”, 2 marca 2009), to szczególny przypadek zastosowania światła w tekście. Pod tytułem i lidem pojawia się dłuższa przestrzeń niezadrukowana. Lid brzmi następująco: „Dlaczego matka 3,5-letniego Bartka pozwoliła go zakatować” („DF”, 2 marca 2009). 


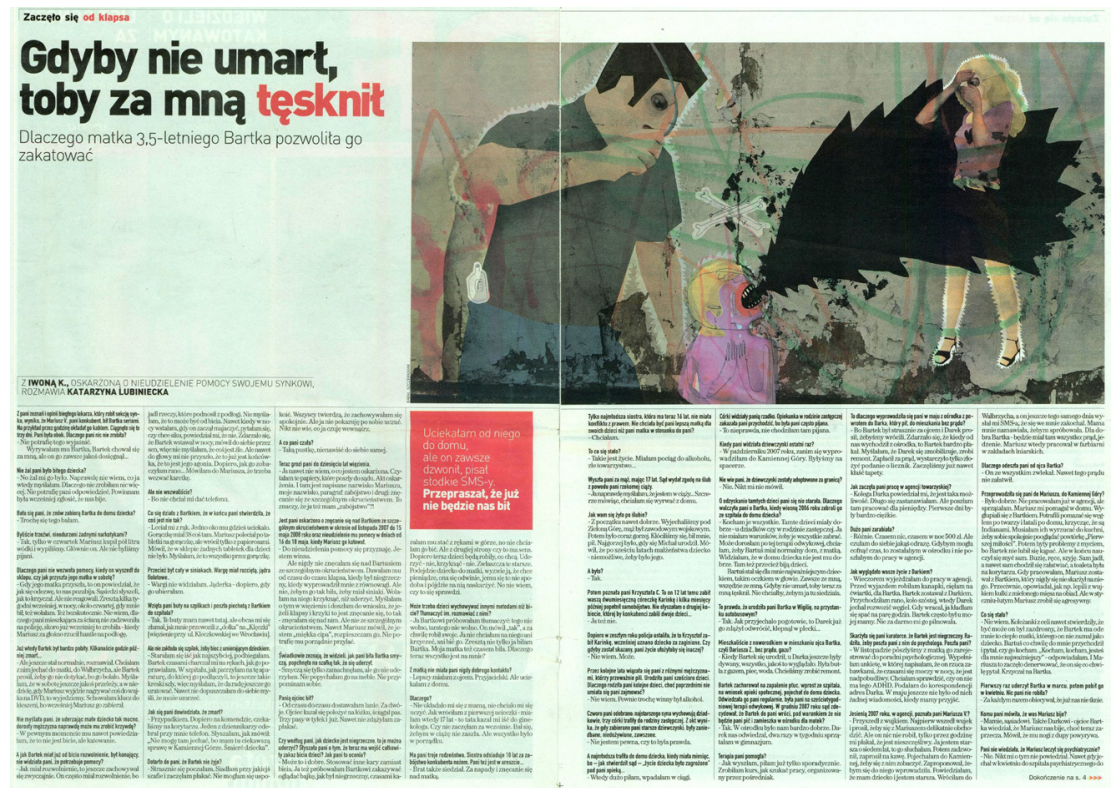

Fot. 7

Źródto: „DF”, 2 marca 2009.

Ta przestrzeń jest niejako „oddechem” tego tekstu, wyraźną przerwą, brakiem odpowiedzi. Po niej następuje wprowadzenie do wywiadu: „Z Iwoną K., oskarżoną o nieudzielenie pomocy swojemu synkowi, rozmawia Katarzyna Lubiniecka” („DF”, 2 marca 2009).

Wywiad to wstrząsająca rozmowa. Przestrzeń niezadrukowana, tak ewidentnie zaznaczona w publikacji, także jest jego wizualizacją. W innym przypadku tak duża proporcja światła mogłaby być traktowana jako pewnego rodzaju błąd graficzny, nieprawidłowe rozplanowanie tekstu. W tej sytuacji gra światłem wzmacnia odbiór tekstu.

Zaprezentowane przykłady grafizacji tekstów doskonale wpisują się w tendencję dziennikarstwa wizualnego. Obrazują także możliwości wizualizacji tekstu poprzez autorskie i redakcyjne panowanie nad nim.

Barbara Kudra wskazuje, że „nadawca może korzystać z wielkiej rozmaitości zapisu tradycyjnego [...] oraz z zupełnie nowych znaków paleograficznych, będących dowodem jego kreatywności komunikacyjnej. Nieokreśloność strategii nadawczej pozwala odbiorcy na różnorodne konkretyzacje i tym sa- 
mym kreatywność (re)interpretacyjną"34. Prezentowane teksty pokazują przede wszystkim kreatywność dziennikarza i jego redakcji, świadomość tego, że warto wizualizować treści w bardzo różnorodny sposób. Tym samym grafizacja tekstów podkreśla interakcyjność prasy, istnienie dialogu między dziennikarzem a jego czytelnikiem.

Zaznaczone graficznie miejsca strategiczne w prasie pomagają czytelnikowi ogarnąć wzrokiem przestrzeń tekstową niejako automatycznie. Natomiast sytuacje szczególnej grafizacji tekstu, wynikające z innego ułożenia tekstu, próby „rysowania” łamów prasowych, gry światłem, czy wprowadzenia infograficznego spisu treści, przyciągają czytelnika swoją nowością, a jednocześnie wzmacniają efekt przekazu werbalnego. Grafizacje przestrzeni tekstowej potęgują jego werbalizację, podkreślają tematykę, punkt widzenia, przedstawiony obraz świata. Nowa architektonika strony daje także możliwość czytelniczej kreatywności w odbiorze, podsuwa dodatkowe możliwości interpretacji tekstu.

\section{Bibliografia}

Ambrose G., Harris P., Layout. Zasady, kompozycja, zastosowanie, Wydawnictwo Naukowe PWN, Warszawa 2008.

Dobrzyńska T., Delimitacja tekstu literackiego, Zakład Narodowy im. Ossolińskich, Wrocław 1974.

Duszak A., Tekst, dyskurs, komunikacja międzykulturowa, Wydawnictwo Naukowe PWN, Warszawa 1998.

Furman W., Gatunki dziennikarskie w praktyce redakcyjnej, [w:] K. Wolny-Zmorzyński, A. Kaliszewski, W. Furman, Gatunki dziennikarskie. Teoria, praktyka, języ, Wydawnictwa Akademickie i Profesjonalne, Warszawa 2006.

Gluza R., Dziennikarstwo wizualne, „Press” 2002, nr 3, s. 44-46.

Grzenia J., O grafizacji pisma, [w:] Spotkanie. Księga jubileuszowa dla Profesora Aleksandra Wilkonia, red. M. Kita, B. Witosz, Wydawnictwo UŚ, Katowice 2005.

Harrower T., Podręcznik projektanta gazet, tłum. W. Horabik, Z. Domaniewska, exPress, Warszawa 2006.

Hopfinger M., Doświadczenia audiowizualne. O mediach w kulturze współczesnej, Sic!, Warszawa 2003.

Kopacz K., Rzemiosło i sztuka, „Press” 2010, nr 10, s. 50-53.

Kress G., van Leeuwen T., Front Pages: (The Critical) Analysis of Newspaper Layout, [w:] The Discourse Structure of the News Stories, ed. A. Bell, P. Garett., Oxford 1998, za: T. Piekot, Dyskurs polskich wiadomości prasowych, Universitas, Kraków 2006.

Kudra B., Grafizacja w nagłówkach prasowych, [w:] Na językoznawczych ścieżkach. Prace ofiarowane Profesorowi Jerzemu Podrackiemu, red. A. Mikołajczuk, R. Pawelec, Wydawnictwo Naukowe Semper, Warszawa 2007.

Maziarski J., Gatunki dziennikarskie, [w:] Encyklopedia wiedzy o prasie, red. J. Maślanka, Zakład Narodowy im. Ossolińskich, Wrocław 1976, s. 89-91.

\footnotetext{
${ }^{34}$ B. Kudra, dz. cyt., s. 155.
} 
Mazurczyk L., Zrozumieć infografikę, [w:] Biblia dziennikarstwa, red. A. Skworz, A. Niziołek, Wydawnictwo Znak, Kraków 2010.

Michalewski K., Komunikaty mieszane, Wydawnictwo UŁ, Łódź 2009.

Niczyperowicz A., Felieton - piękny pasożyt, [w:] Dziennikarstwo od kuchni, red. A. Niczyperowicz, TS Wydawnictwo, Poznań 2001.

Pacuła J., Grafizacja i wizualizacja słowa w zapowiedziach medialnych, „Media i Społeczeństwo” 2012, nr 2, s. 74-93.

Piekot T., Werbalizacja i wizualizacja w dyskursie wiadomości prasowych, [w:] Ikoniczność znaku: słowo - przedmiot - obraz - gest, red. E. Tabakowska, Universitas, Kraków 2006, s. 99-116.

Starzec A., Rola infografów w tekstach prasowych o tematyce naukowej, [w:] Oblicza komunikacji 1. Perspektywy badań nad tekstem, dyskursem i komunikacja, red. I. Kamińska-Szmaj, T. Piekot, M. Zaśko-Zielińska, Krakowskie Towarzystwo Popularyzowania Wiedzy o Komunikacji Językowej „Tertium”, Kraków 2006, s. 245-258.

Ślawska M., Wywiady w formie komiksu, czyli o modyfikacjach gatunkowych na tle procesów konwergencji, [w:] Konwergencja mediów i jej skutki dla współczesnego dziennikarstwa, t. 1, red. M. Wielopolska-Szymura, Z. Oniszczuk, Wydawnictwo UŚ, Katowice 2012, s. 399-408.

Ślawska M., Formy dialogu w gatunkach prasowych, Wydawnictwo UŚ, Katowice 2014.

Wojtak M., Gatunki prasowe, Wydawnictwo UMCS, Lublin 2004.

Wojtak M., Analiza gatunków prasowych. Podręcznik dla studentów dziennikarstwa i kierunków pokrewnych, Wydawnictwo UMCS, Lublin 2008.

Wolny-Zmorzyński K., Kaliszewski A., Furman W., Gatunki dziennikarskie. Teoria, praktyka, język, Wydawnictwa Akademickie i Profesjonalne, Warszawa 2006.

Wolny-Zmorzyński K., Fotograficzne gatunki dziennikarskie, Wydawnictwa Akademickie i Profesjonalne, Warszawa 2007.

Worsowicz M., Lektura, pilotaż, nawigowanie - o grafizacji materiałów dziennikarskich na przykładzie jedynek „Dziennika Łódzkiego”, [w:] Komunikacja wizualna w przestrzeni społecznej, red. A. Obrębska, Wydawnictwo Primum Verbum, Łódź 2009, s. 101-110.

Worsowicz M., Edytorstwo prasowe - zagadnienia ogólne, [w:] O mediach i komunikacji. Skrypt dla studentów dziennikarstwa i komunikacji społecznej, red. E. Pleszkun-Olejniczakowa, J. Bachura, M. Worsowicz, Wydawnictwo UŁ, Łódź 2010, s. 129-140.

Żydek-Bednarczuk U., Wprowadzenie do lingwistycznej analizy tekstu, Universitas, Kraków 2005.

Magdalena Ślawska

\section{Graphization in the press, i.e. several examples of the spatial organization of press texts}

\section{(Summary)}

In the article, the author underlines that each press text is a macrostructure, organized by key elements (for example: titles, leads, initial and final fragments, photographs). Those elements in the press are isolated and graphically designed by authors and editors. The author considers the graphic shape of the text as a certain form of its visualization. In the article, the author refers to several texts from "Duży Format" (a supplement to the "Gazeta Wyborcza" daily), where textual 
space is visualized in various manners. The author points out multi-voice structures, the atypical lay-out of press columns in the fashion of photographs, introduction of infographics into reports, playing with light, or incorporating the text into the graphics. The represented examples of text graphization fit into the tendency of visual journalism, and at the same time prompt the viewer with additional possibilities for the interpretation of press texts.

Keywords: macrostructure, strategic places in a text, infographics, graphization, text visualization. 